\title{
WAYANG GODHONG SEBAGAI MEDIA EDUKASI CINTA BUDAYA DAN ALAM SEJAK USIA DINI
}

\author{
Agus Purwanto ${ }^{1}$, Ercilia Rini Octavia², Sigit Purnomo Adi $^{3}$ \\ ${ }^{1,3}$ Seni Rupa Murni, FSRD - Universitas Sebelas Maret \\ ${ }^{2}$ Desain Komunikasi Visual, FSRD - Universitas Sebelas Maret \\ goespoer13@staff.uns.ac.id ${ }^{1}$, erciliaoctavia@staff.uns.ac.id ${ }^{2}$, sigitpurnomoadi61@gmail.com ${ }^{3}$
}

\begin{abstract}
Abstrak
Seiring dengan perkembangan zaman, pertunjukan wayang berfungsi menjadi media pembelajaran. Demikian halnya dengan Wayang Godhong. Wayang kontemporer yang berasal dari godhong (daun) jati, cengkeh, dan kopi ini mencoba menjadikan pertunjukan wayangnya sebagai media edukasi cinta budaya dan alam sejak usia dini di Kabupaten Magelang. Artikel yang disusun melalui metode penelitian kualitatif deskriptif ini, berhasil menemukan visualisasi figur/karakter Wayang Godhong yang representatif untuk anak usia dini dengan pendekatan visual yang ramah dan lucu. Kemudian proses penyampaian dalang Wayang Godhong saat pentas yang harus menggunakan mimik jelas (karena dalang di depan anak-anak, tidak di balik layar), sehingga bahasa yang digunakan pun harus bahasa yang mudah dipahami anak-anak dengan penyampaian humorisme. Setelah melihat pementasan, anak-anak pun berkeinginan melakukan seperti yang dipesankan dalam pementasan yakni menanam pohon sebagai upaya melestarikan alam ini serta menjadi suka/cinta akan wayang. Dengan demikian Wayang Godhong dianggap mampu menjadi media edukasi cinta wayang sebagai hasil dari budaya Indonesia dan cinta alam dengan menanam/merawat pohon sejak usia dini.
\end{abstract}

Kata Kunci: budaya dan alam, media edukasi, anak usia dini, Wayang Godhong

\begin{abstract}
Along with the times, puppet shows function as learning media. Like wise with Wayang Godhong. Wayang Godhong, a form of contemporary wayang made from leaves of teak, cloves, and coffee, attempts to become a medium for children to foster a sense of love for nature and culture, especially in the Magelang Regency. This article, compiled through descriptive qualitative research methods, has succeeded in finding the visualization of the representative Wayang Godhong figures/characters for early childhood with a friendly and funny visual approach. The performance process of storytelling by the puppeteer must be used a clear facial expression (because the puppeteer stays in front of the children, not behind the scenes), the language must be easy to understand by the children by conveying humorism. After seeing the performance, the children wanted to do as instructed in the wayang performance, such as planting trees as an effort to preserve nature and became interested in wayang. Thereby, Wayang Godhong is considered capable of being a love for wayang educational media as a result of Indonesian culture and love for nature by planting/caring for trees from an early age.
\end{abstract}

Keywords: children, culture and nature, education media, Godhong puppet 


\section{PENDAHULUAN}

Perkembangan anak usia taman kanak-kanak 4-6 tahun terjadi sangat pesat, anak mulai belajar menguasai pada tingkat yang lebih tinggi dari aspek- aspek: gerakan, berpikir, perasaan, dan interaksi baik dengan sesama maupun dengan benda-benda dalam lingkungan hidupnya. Menurut Montessori (2013), pada masa perkembangan tersebut anak dikatakan dalam periode sensitif atau masa peka, dimana suatu fungsi tertentu perlu dirangsang, diarahkan, sehingga tidak terhambat perkembangannya. Mengingat urgennya masa kanak-kanak sebagai pondasi karakter seseorang jika kelak ia tumbuh dewasa, maka pada masa usia 4-6 tahun tersebut selain perlu dirangsang fisikmotoriknya, diperlukan juga pengasahan terhadap intelektual, sosial, dan emosinya dengan nilai-nilai baik yang berlaku dalam masyarakat dimana ia tinggal.

Bentuk rangsangan pertumbuhan anak usia dini bertujuan untuk merangsang kematangan budi anak didik, yaitu kehalusan perasaan (moral), yang kemudian akan menghasilkan kecerdasan pikiran, dan membuahkan kekuatan kehendak. Untuk mendidik perasaan, Ki Hajar Dewantara (dalam Muchammad Tauchid, 2013) mengatakan ada 2 hal yang harus dilalui, pertama pendidikan kehalusan hidup kebathinan yang dinamakan pendidikan moral dan yang kedua adalah pendidikan estetis. Wayang oleh Ki Hajar Dewantara dimasukkan sebagai pendidikan estetis yang dapat menghaluskan perasaan keindahan terhadap segala benda lahir. Wayang yang awalnya digunakan dalam pertunjukan tertransformasi menjadi media untuk menyampaikan sebuah ajaran (pendidikan). Wayang sebagai hasil olah budaya manusia Indonesia yang adiluhung telah ikut membentuk budaya nasional Indonesia saat ini sebagai bagian dari budaya dunia.

Demikian halnya dengan Wayang Godhong. Wayang kontemporer yang dibuat dari godhong (daun) jati, cengkeh, dan kopi merupakan buah dari gagasan Agus Purwanto (dikenal dengan nama Gus Pur). Penciptaan wayang ini bermula dari adanya empati terhadap resistensi petani tembakau pada tahun 2010. Gus Pur yang bertutur melalui Wayang Godhong ini mencoba mentransformasi fungsi wayang yang awalnya sebagai karakter dalam pertunjukan saja kemudian diubah menjadi media edukasi untuk menyampaikan kisah-kisah tentang kebajikan dan pesan tentang kehidupan. Banyak pertunjukan yang telah dilakukan Gus Pur terkait dengan kegiatan edukasi, salah satunya pertunjukkan yang bertujuan mengedukasi masyarakat Magelang tentang cinta terhadap budaya dan alam sejak usia dini. Pementasan ini berjudul "Guru Kencing Berdiri, Anak Kencing Berlari" yang dilakukan di TK PAUD Harapan Bunda Kabupaten Magelang pada 9 Maret 2020.

Sebelum penelitian ini dilakukan, telah ada penelitian terdahulu yang juga menyoal wayang sebagai media penyampai pesan (edukasi), diantaranya: Pertama, penelitian Eko Purwanto dan Margareta Evi Yuliana, berjudul "Penerapan Animasi Pertunjukan Wayang Sebagai Media Pendidikan Budi Pekerti dan Memperkenalkan Budaya Bangsa Kepada Anak Usia Dini" tahun 2016 ini merancang wayang melalui media animasi dengan file exe dan di-burn sebagai proses pendistribusiannya. Kedua, penelitian berjudul "Pengembangan Media Pembelajaran Pendidikan Seni Budaya Berbasis 
Kearifan Lokal (Wayang Sebagai Sumber Gagasan)" tulisan Tjetjep Rohendi Rohidi tahun 2014. Hasil penelitian menunjukkan sub kebudayaan Jawa menyimpan segudang potensi berbasis kearifan lokal, wayang sebagai salah satunya. Selanjutnya penelitian ketiga yaitu tulisan Dessi Stifa Ningrum (2014) berjudul “Peran Tokoh Punakawan Dalam Wayang Kulit Sebagai Media Penanaman Karakter Di Desa Bendosewu Kecamatan Talun Kabupaten Blitar". Penelitian ini membuktikan bahwa tokoh punakawan dalam wayang kulit dapat dijadikan sebagai media penanaman karakter di Desa Bendosewu Kecamatan Talun Kabupaten Blitar.

Beberapa penelitian di atas menyebutkan tentang wayang sebagai media penyampai pesan dalam visualisasi wayang yang berbeda-beda. Namun, penelitian tidak satu pun yang menggunakan daun kopi, cengkeh dan jati sebagai bahan dasar pembuatan/media wayang serta menturutkan interaksi langsung dengan target audience-nya untuk turut berperan aktif dalam instruksi yang dipesankan melalui pertunjukan wayang seperti yang dilakukan oleh Wayang Godhongnya Gus Pur ini. Oleh sebab itu melalui metode penelitian dengan pendekatan kualitatif deskriptif yang berjudul Wayang Godhong Sebagai Media Edukasi Cinta Budaya dan Alam Sejak Usia Dini ini, menjelaskan tentang; (1) visualisasi Wayang Godhong sebagai media edukasi cinta budaya dan alam sejak usia dini di Kabupaten Magelang (2) proses pertunjukan Wayang Godhong sebagai media edukasi untuk mengenalkan cinta budaya dan alam sejak usia dini di Kabupaten Magelang, serta (3) tentang efektivitas penerapan Wayang Godhong sebagai media edukasi cinta budaya dan alam yang representatif sejak usia dini di Kabupaten Magelang.

\section{METODE PENELITIAN}

Penelitian ini menggunakan pendekatan kualitatif deskriptif, yang bersifat fleksibel dan terbuka untuk perubahan dan penyesuaian pada saat penelitian sehingga tidak ada batasan bagi peneliti untuk menemukan hal-hal baru yang terkait dengan topik penelitian (Bungin, 2003: 49). Metode pengumpulan data dilakukan melalui: (1). Wawancara Mendalam (in depth interviewing), (2). Observasi lapangan di PAUD Harapan Bunda, secara langsung digunakan karena mampu menangkap keadaan sosial alamiah tempat terjadinya perilaku, dapat menangkap peristiwa yang mempengaruhi relasi sosial para partisipan dan mampu mengidentifikasi keteraturan dan gejala yang berulang dalam kehidupan sosial dengan membandingkan dan melihat perbedaan dari data yang diperoleh dalam suatu studi (Black and Champion, 1992: 286).

Penelitian ini menggunakan pendekatan kualitatif deskriptif, yang bersifat fleksibel dan terbuka untuk perubahan dan penyesuaian pada saat penelitian sehingga tidak ada batasan bagi peneliti untuk menemukan hal-hal baru yang terkait dengan topik penelitian (Bungin, 2003: 49). Metode pengumpulan data dilakukan melalui: (1). Wawancara Mendalam (in depth interviewing), (2). Observasi lapangan di PAUD Harapan Bunda, secara langsung digunakan karena mampu menangkap keadaan sosial alamiah tempat terjadinya perilaku, dapat menangkap peristiwa yang mempengaruhi relasi sosial para partisipan dan mampu mengidentifikasi keteraturan dan gejala yang 
berulang dalam kehidupan sosial dengan membandingkan dan melihat perbedaan dari data yang diperoleh dalam suatu studi (Black and Champion, 1992: 286).

Proses analisis data dilakukan dengan menelaah seluruh data yang tersedia dari berbagai sumber, mengacu pada tahapan yang dijelaskan Miles dan Huberman (lihat Bagan Metode Analisis Model Interaktif) antara lain: 1). Pengumpulan; 2). Reduksi data (data reduction); 3). Penyajian data (data display; 4). Pada tahap akhir adalah penarikan kesimpulan atau verifikasi (conclusion drawing/verification), yang mencari arti pola-pola penjelasan, konfigurasi yang mungkin, alur sebab akibat dan proposisi. Penarikan kesimpulan dilakukan secara cermat dengan melakukan verifikasi berupa tinjauan ulang pada catatan-catatan di lapangan sehingga data dapat di uji validitasnya.

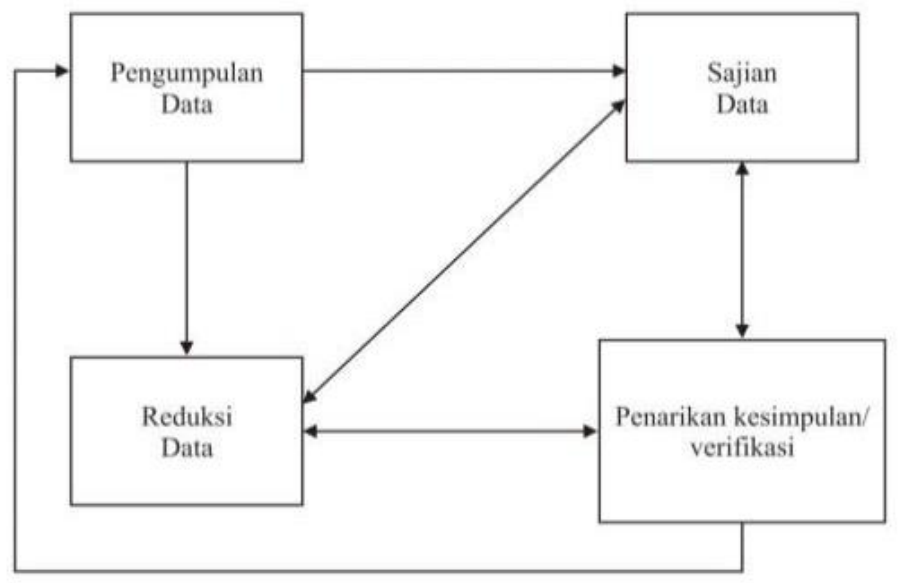

Gambar 1. Bagan metode analisis Model Interaktif [Sumber: Miles dan Huberman, 2009: 20]

\section{HASIL DAN PEMBAHASAN}

\subsection{Visualisasi Wayang Godhong}

Wayang Godhong ini mirip dengan wayang-wayang kulit lainnya dalam proses pembuatannya, bahannya saja yang berbeda, yakni menggunakan daun serta acrylic. Daunnya biasanya daun kering, bisa daun cengkeh, daun kopi. Proses pembuatannya dimulai dengan membuat draft /sket kasar terlebih dahulu dengan menggunakan pensil/spidol sesuai dengan bentuk karakter yang diharapkan. Setelah draft/sket selesai tinggal diberi warna menggunakan cat acrylic dan bambu untuk pegangan wayang. Berikut ini foto proses pembuatannya: 


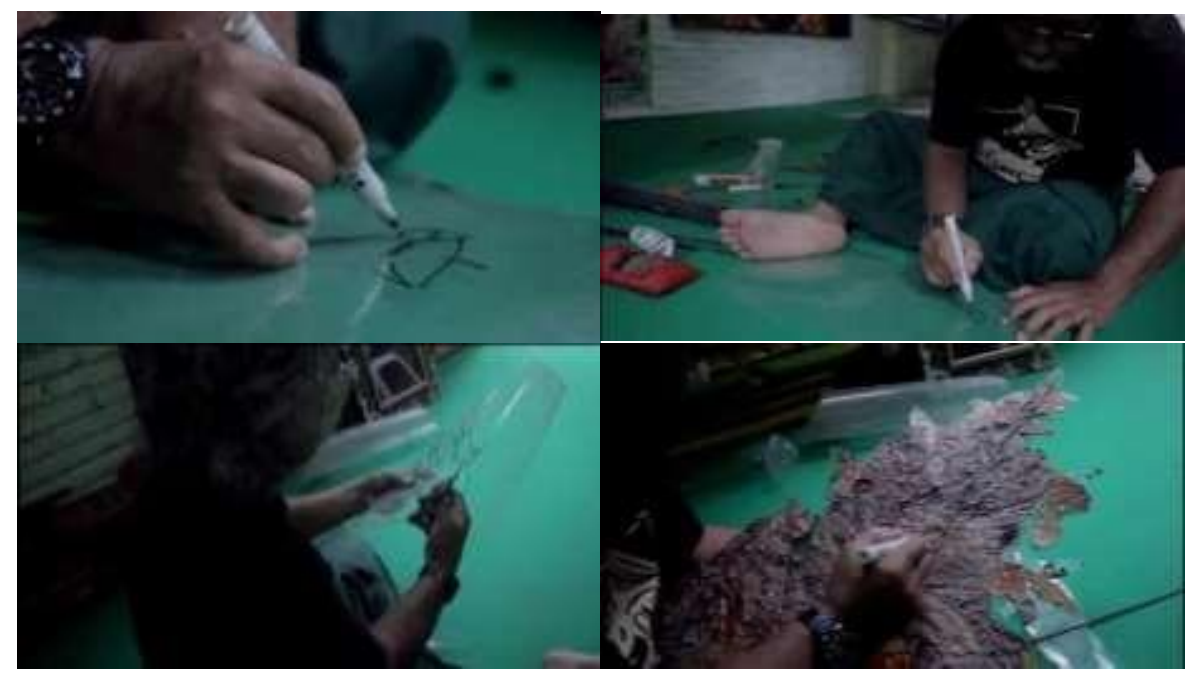

Gambar 2. Proses Pembuatan Karakter/Tokoh Wayang Godhong

[Sumber: Dokumentasi Penulis]

Visualisasi gunungan (simbol alam semesta) dalam wayangnya berubah-ubah tergantung dari tema yang diangkat. Tokoh-tokoh/karakter-karakter Wayang Godhong juga divisualisasikan kecil-kecil karena memang dibuat untuk tujuan merepresentasikan rakyat kecil. Biasanya terdiri dari dua tokoh pokok yang selalu ada, yaitu tokoh Wayang Gus Pur dan Bu Rinah. Visualisasi tokoh digunakan sebagai media dialektika komunikatif. Tentunya dalam komunikasinya tersebut digunakan banyak dedaunan. Kemudian visualisasi dari karakter Wayang Godhong sebagai berikut;
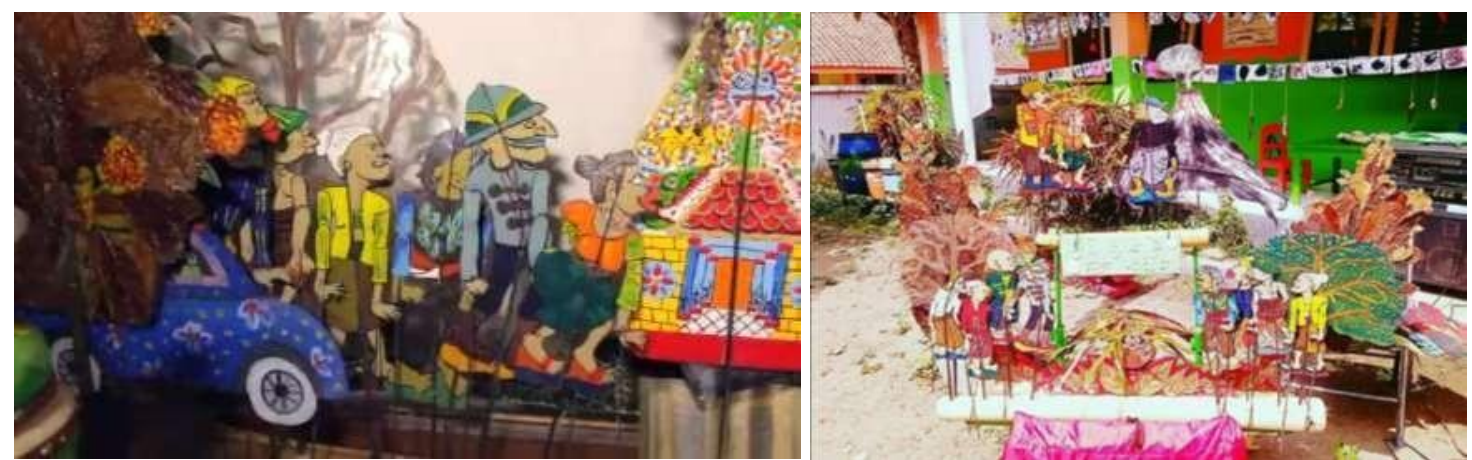

Gambar 2. (kiri) Visualisasi Karakter/Tokoh Gus Pur dan Bu Rinah, (kanan) Visualisasi Semua Karakter/Tokoh Wayang Godhong dalam Pementasan di PAUD Harapan Bunda 9 Maret 2020

[Sumber: Dokumentasi Penulis]

\subsection{Proses Wayang Godhong Bertransformasi}

Gus Pur selaku pencipta wayang ini bertekad menyadarkan manusia untuk menghargai alam. Gus Pur yang bertutur melalui Wayang Godhong ini mencoba mentransformasi fungsi wayang yang awalnya sebagai karakter dalam pertunjukan saja kemudian diubah menjadi media edukasi untuk menyampaikan kisah-kisah tentang kebajikan dan pesan tentang kehidupan terutama tentang alam sebagai karunia agung dari Tuhan Yang Maha Esa. Diantara sekian banyak pementasanya, Wayang Godhong juga mengadakan pertunjukkan yang bertujuan mengedukasi masyarakat Magelang tentang cinta 
terhadap budaya dan alam sejak usia dini. Pertunjukan/pementasan ini dilakukan di PAUD Harapan Bunda.

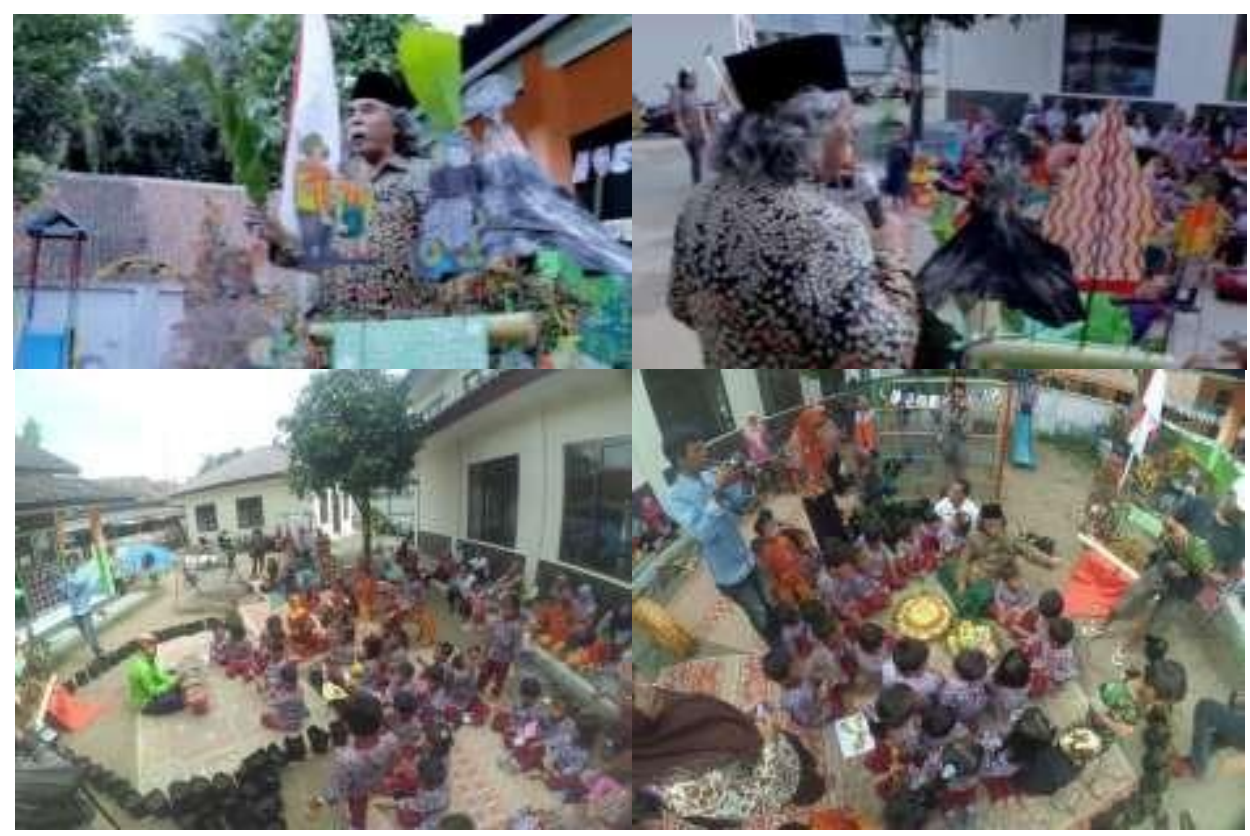

Gambar 4. Proses Pertunjukan/Pementasan Wayang Godhong berjudul "Guru Kencing Berdiri, Murid Kencing Berlari” di PAUD Harapan Bunda Magelang Senin, 9 Maret 2020

[Sumber: Dokumentasi Penulis]

Pementasan ini lengkap dilihat oleh 35 murid-murid PAUD Harapan Bunda Magelang, serta guru dan Ibu Kepala Sekolahnya. Pementasan yang dilakukan di PAUD Harapan Bunda Kabupaten ini berjudul "Guru Kencing Berdiri, Murid Kencing Berlari" dilaksanakan pada 9 Maret 2020. Bagi murid-murid PAUD Harapan Bunda yang masih kanak-kanak (berusia dini) ini tentu memiliki keleluasaan untuk kencing sambil berlari. Guru kanak-kanak harus memiliki pemahaman bahwa cara kencing berlari anak-anak merupakan nalar polos, yang berbeda dengan nalar kritis anak SMP maupun SMA. Nalar polos anak-anak menuntut guru untuk memberi tauladan yang baik dengan memberikan pengertian atau pemahaman mengenai perilaku sebagai pola kebiasaan sehari- hari. Dengan pemahaman demikian, maka kencing sambil berlari bukan untuk dinilai sebagai suatu kebiasaan yang baik atau buruk, melainkan bagaimana guru memberi/memasukkan pendidikan yang baik melalui peristiwa murid kencing berlari itu.

Selain itu, tujuan intinya adalah untuk mengajak anak dari usia dini supaya mengetahui eksistensi wayang sebagai bentuk budaya (tradisi) yang harus diuri- uri. Serta mengajak anak-anak ini untuk mencintai alam dengan menanam tanaman dan memberinya pupuk urine/kencing. Karena air kencing mengandung tiga unsur hara makro yaitu nitrogen, phospor, dan kalium serta magnesium, kalsium, dan karbon untuk memperbaiki pertumbuhan vegetatif tanaman, meningkatkan kadar asam amino sekaligus protein pada tanah, meningkatkan jumlah daun, dan meningkatkan warna hijau daun yang nantinya berfungsi dalam proses fotosintesis karena kandungan klorofil yang tinggi, dan 
membantu meningkatkan $\mathrm{pH}$ tanah yang berfungsi dalam penyerapan unsur hara. Maka dari itu setelah pementasan ini, anak-anak diajak melakukan kegiatan menanam di polybag.

\subsection{Efektifitas Wayang Godhong sebagai Media Transformasi Edukasi Seni Budaya dan Cinta Alam}

Pementasan Wayang Godhong sebagai media edukasi seni budaya dan cinta alam bertajuk "Guru Kencing Berdiri, Murid Kencing Berlari" di PAUD Harapan Bunda Magelang ini, membawa kesan yang baik bagi setiap guru yang saat itu menonton, terutama bagi murid-muridnya yang merasa beruntung bisa bersinggungan bertemu langsung dengan dalang/seniman Wayang Godhog, menyimak cerita melalui pertunjukan wayang, serta melakukan kegiatan menanam. Berikut prosentase yang diperoleh saat beberapa pertanyaan dibawah ini ditanyakan pada ke-35 murid di PAUD Harapan Bunda setelah pementasan dan penanaman pohon usai;

1) $58 \%$ anak pernah melihat pertunjukan wayang, melihat secara langsung bersama orangtuanya, melihat melalui televisi juga youtube. Sedangkan $42 \%$ anak-anak belum pernah melihat pertunjukan wayang

2) $86 \%$ menganggap tokoh wayang maupun cara dalang Gus Pur mementaskan Wayang Godhong, lucu. $12 \%$ ada yang gemes, namun $2 \%$ ada yang mengaku takut sama dalangnya ketika bersuara tinggi.

3) $80 \%$ anak-anak PAUD Harapan Bunda paham akan konten cerita dalam pertunjukan Wayang Godhong berjudul "Guru Kencing Berdiri, Murid Kencing Berlari. Kemudian $20 \%$ nya ragu-ragu dan malu saat menjawab.

4) $84 \%$ anak-anak berjanji mau menanam pohon, merawat dan memupuknya.

5) $91 \%$ anak-anak PAUD Harapan Bunda menyukai pementasan Wayang Godhong dan aktifitas menanam pohon di polybag.

Berdasarkan dari hasil wawancara dengan ke-35 murid-murid PAUD Harapan Bunda, dapat disimpulkan bahwa sebagian besar sudah pernah melihat wayang tetapi dominan bukan melihatnya secara langsung dalam pementasan. Saat diadakan pementasan Wayang Godhong di sekolahnya, murid-murid ini dominan merasa senang, merasa dalang menyampaikan isi cerita tentang "Guru Kencing Berdiri, Murid Kencing Berlari" menyenangkan. Sehingga, anak-anak berkenan dan senang saat diajak menanam pohon di polybag. Mereka berjanji untuk mau merawat, menyiram, dan memupuk tanamannya. Sayangnya setelah penelitian ini dilakukan, terjadi Kondisi Luar Biasa Covid 2019, sehingga kegiatan murid-murid menyiram dan memupuk pohon yang sudah ditanam di sekolah terhenti pada saat setelah diberlakukannya belajar di rumah mulai 14 Maret 2020. Kemudian selain testimoni dari murid-murid tersebut, Ibu Kepala Sekolah pun (Ibu Sumarsih, S.Pd) mengutarakan pendapatnya sebagai berikut: "Wayang Godhong sangat bagus karena itu belum pernah ada pentas/pertunjukan wayang ya baru kali ini. Makna/inti daripada cerita Wayang Godhong akan dijadikan dasardasar/pengetahuan untuk mendidik pada anak didiknya sehingga akan terbiasa mengetahui mana yang bagus dan mana yang tidak. Kita harus mempertahankan budaya Jawa. Serta cinta alam ini" 


\section{KESIMPULAN}

Umumnya dahulu, pertunjukan wayang berisi tentang cerita-cerita di dunia pewayangan, namun seiring dengan perkembangan zaman, pertunjukan wayang bertransformasi menjadi media untuk menyampaikan sebuah ajaran (pendidikan). Demikian halnya dengan Wayang Godhong, yakni wayang kontemporer yang berasal dari godhong (daun) jati, cengkeh, dan kopi merupakan buah dari gagasan Gus Pur menjadikan pertunjukan wayangnya sebagai media transformasi edukasi cinta budaya dan alam sejak usia dini di PAUD Harapan Bunda Kabupaten Magelang. Edukasi tersebut dilakukan melalui pementasan Wayang Godhong berjudul "Guru Kencing Berdiri, Murid Kencing Berlari". Sebagian besar murid-murid sudah pernah melihat wayang tetapi dominan bukan melihatnya secara langsung dalam pementasan. Saat diadakan pementasan Wayang Godhong di sekolahnya, murid-murid ini dominan merasa senang, merasa dalang pun bercerita dengan gaya yang humoris dan menyenangkan. Sehingga, anak-anak berkenan dan senang saat diajak berlaku sesuai anjuran/pesan dalam pementasan, yakni untuk mencintai wayang sebagai bagian dari kekayaan seni budaya Indonesia, Jawa khususnya serta mau menanam pohon. Mereka pun akhirnya menanam bersama pohon di polybag- polybag yang telah disediakan serta berjanji untuk mau merawat, menyiram, dan memupuk tanamannya. Dengan demikian melalui pendekatan media Wayang Godhong ini, anak usia dini mengenal bentuk seni budaya kontemporer sekaligus memahami pesan yang disampaikan untuk mencintai alam dan melestarikannya sebagai wujud anugerah Tuhan Yang Maha Esa.

\section{DAFTAR PUSTAKA}

Creswell, John. W. (2009). Research Design: Pendekatan Kualitatif, Kuantitatif, dan Mixed, terjemahan Achmad Fawaid. (2014). Yogyakarta: Pustaka Pelajar.

Dewantara, Ki, Hadjar. (2013). Bagian Pertama; Pendidikan. Yogyakarta: Majelis Luhur Persatuan Tamansiswa.

Hurlock, Elisabeth. (1996). Psikologi Perkembangan. Surabaya: Erlangga.

Miles, Matthew B. dan A. Michael Huberman. (1984). Qualitative Data Analysis atau Analisis Data Kualitatif, terjemahan Tjetjep Rohendi Rohidi. (2009). Jakarta: Universitas Indonesia Press.

Moleong, Lexy J. (2011). Metodologi Penelitian Kualitatif. Bandung: Remaja Rosdakarya.

Ningrum, Dessi Stifa. (2014). Peran Tokoh Punokawan Dalam Wayang Kulit Sebagai Media Penanaman Karakter di Desa Bendosewu Kecamatan Talun Kabupaten Blitar. Malang: Universitas Negeri Malang. Tersedia di http://repository.um.ac.id/51824/ (diakses Januari 2020)

Nurgiyantoro, Burhan. (2011). Wayang dan Pengembangan Karakter Bangsa. Jurnal Pendidikan Karakter. Volume (1), Nomer 1.

Patton, Michael Quinn. (2002). Qualitative Research \& Evaluation Methods. California: Sage Publications Inc.

Purwanto, Sigit. (2018). Nilai Pendidikan dalam Pagelaran Wayang. Ta'alum Jurnal Pendidikan Islam. Volume 06, Nomor 1, Halaman 1-30 
Purwanto, Eko, dan Evi, Margareta Yulianan. (2016). Penerapan Animasi Pertujukan Wayang Sebagai Media Pendidikan Budi Pekerti dan Memperkenalkan Budaya Bangsa Kepada Anak Usia Dini. Jurnal Sainstech Politeknik Indonusa. Volume 1 Nomor 6.

Rohendi, Tjetjep. (2014). Pengembangan Media Pembelajaran Pendidikan Seni Budaya Berbasis Kearifan Lokal (Wayang Sebagai Sumber Gagasan). Jurnal Imajinasi. Volume 7, Nomor 1.

Sugiyono. (2007). Memahami Penelitian Kualitatif. Bandung: CV. Alfabeta. 